\title{
Destination Choice Intention of Young Tourist: A Comparative Study Between Indonesia and Thailand
}

\author{
Nathalia Ramadhania ${ }^{1}$, Jono Munandar ${ }^{2}$, Nirundon Tapachai ${ }^{3}$ \\ \{ramadhania_natha@apps.ipb.ac.id,jonmu@apps.ipb.ac.id², ntapachai@yahoo.com ${ }^{3}$ \} \\ Faculty of Economics and Management, IPB University ${ }^{1,2}$, Faculty of Business Administration, Kasetsart \\ University $^{2}$
}

\begin{abstract}
Indonesia and Thailand are included in the top destinations for international visitors in ASEAN and tourism industry also plays a major role in contributing both countries' GDP. Young tourist is becoming more and more a target to keep an eye on in tourism industry because travellers ages 15 to 29 accounted for an estimated 23\% of all international travellers in 2015. Despite the enormous market, there is still limited study in youth tourism context. Previous research suggested that understanding the influence of consumption values towards the attitude to visit a destination is important and also there is a lack of literature in studying how travelers evaluate images of destinations that they have not visited, therefore this study examined how is the perceived image of Indonesia and Thailand by young tourist, their consumption values, and their intentions to visit the country. The data were collected by questionnaire and analyzed using SEM PLS. The results of this study is consumption values and eWOM have significant influence on perceived beneficial image. Consumption values and eWOM have significant influence on destination choice intention to Thailand for Indonesia young tourist, while perceived beneficial image only has significant influence on destination choice intention to Indonesia for Thailand young tourist.
\end{abstract}

Keywords: Consumption Values, Destination Choice Intention, eWOM, Perceived Beneficial Image, SEM PLS, Young tourist

\section{Introduction}

Tourism has now become one of the major growth-generating sectors for low and middle income countries. Tourism does not only contribute in generating economic activities, but also in generating more employment and revenues. Growth in tourism industry can be seen as an indicator of economic development because it generates significant foreign exchange earnings. ASEAN is one of the regions 
which is very dependent on tourism, with the total of travel and tourism contribution $12,4 \%$ to the total Gross Domestic Product (GDP), which is almost $4 \%$ higher than most of the other world's regions [1]. Travelling to ASEAN also offers unlimited of variety starting from the culture, landscape, food, entertainment, and others. Tourists who visit ASEAN can experience from wildlife to city life to snow, from mountains to dense tropical rainforests, and from serene beach life to a busting city life [2].

Indonesia and Thailand are included in the top destinations for international visitors in ASEAN. Travel and tourism industry in both countries also play a major role in contributing for the country's GDP. According to Knoema Statistic [3], travel and tourism industry contributed around THB 3.229 billions or $21.2 \%$ to Thailand's GDP. While in Indonesia, in 2018 travel and tourism countributed 6\% to GDP, and is projected to grow by $5.2 \%$ in 2019 .

In 2018, Thailand has the highest rank in terms of numbers of tourist arrivals in Southeast Asia Countries with approximately 38.3 milion international visitors, while Indonesia is in the fourth rank with approximately 15.8 million international visitors [4]. According to ASEAN Statistics [5], the number of Indonesian tourists who visited Thailand in 2018 was 644.043 while the number of Thailand tourists who visited Indonesia was only 124.153. Figure 1 below also shows that the numbers of Indonesia visitors to Thailand consistently increase while the numbers of Thailand visitors to Indonesia decreased in 2018. This raised questions on the contributing factors that have attracted Indonesia visitors to Thailand.

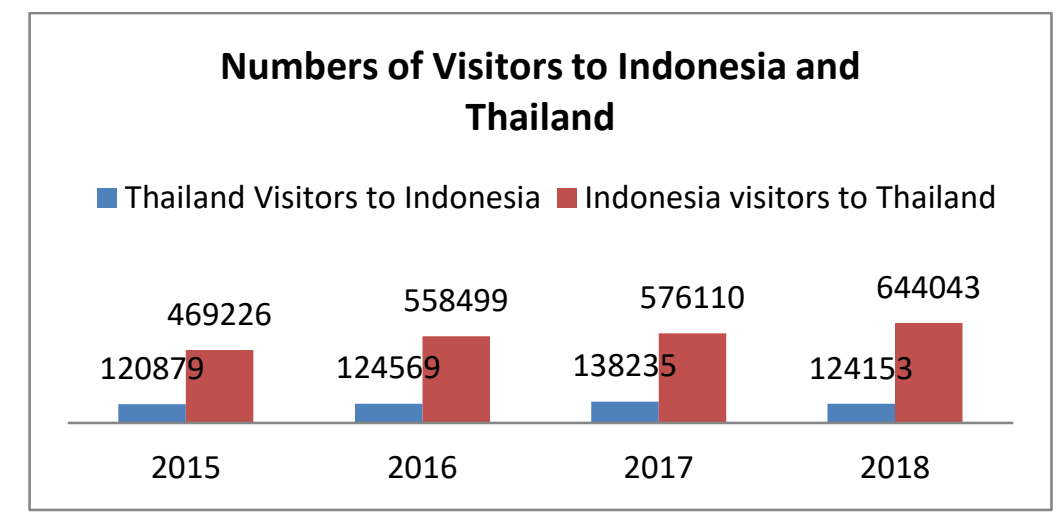


Figure 1. Numbers of Visitors to Indonesia and Thailand Source: ASEAN Data Statistics

Nowadays, youth travellers are dominant market for travel destinations around the world. Data from United Nations World Tourism Organization [6] showed that youth travellers with age range 15 to 29 dominated for an estimated $23 \%$ of all international travellers in 2015. Data from Scoot Airlines [7] also showed that Bangkok is the favorite travel destination for Indonesian millenials, followed by Hongkong, while data from Thai Embassy [8] showed that Thais favorite travel destination is Japan, Malaysia, and Laos. Debski and Nasierowski [9] found that the important drivers related to how the youth travelers select their destination to travel are the cost of travelling and the overall variety and the quality of the destination. Though according to the Travel and Tourism Competitiveness Report [10] Thailand, Malaysia, and Japan has a better overall rank than Indonesia, Indonesia has a better score in price competitiveness than Thailand and Japan.

Table 1. Travel and Tourism Competitiveness Score 2019

\begin{tabular}{lllll}
\hline & $\begin{array}{l}\text { Overall } \\
\text { Score }\end{array}$ & $\begin{array}{l}\text { Price } \\
\text { Competitiveness }\end{array}$ & $\begin{array}{l}\text { Natural } \\
\text { Resources }\end{array}$ & $\begin{array}{l}\text { Cultural } \\
\text { Resources }\end{array}$ \\
\hline Indonesia & 4.3 & 6.2 & 4.5 & 3.2 \\
\hline Thailand & 4.5 & 5.8 & 4.8 & 2.6 \\
\hline Malaysia & 4.9 & 6.3 & 3.8 & 2.6 \\
\hline Japan & 5.4 & 4.8 & 4.1 & 6.5
\end{tabular}

Source: World Economic Forum (2019)

ASEAN Youth Development Index [11] stated that the population of youth (15-29 years) in Indonesia is $25 \%$ of the total population, while in Thailand, youth (15-29 years) comprise $23 \%$ of the total population. According to Allied Market Research's data in Twissen.com [12], Millennials contribute 200 billion dollars for the Travel \& Tourism industry, and Gen Zs are going to represent $40 \%$ of all consumers by 2020. Virtuoso's Luxe Report [13] also stated that the Gen Z preferences will represent one of the most important factors which are going to impact the families' travel choices. Social media websites are also dominating as a 
source of information for travel and tourism, rather than information from travel suppliers [14]. Since Millenial and Generation $Z$ consumers will dominate the number of travellers in the future, it is very crticial for tourism managers to understand young travellers better; otherwise, the risk of spreading the negative electronic Word of Mouth is high [15].

There is still not enough research on young tourists' travel motivation, expectation, and intention, eventhough the market size of young tourists keep increasing nowadays [16]. Research on young tourists is often overshadowed by studies within the mass and adult tourist market [17]. Research showed that destination image influences the tourists' attitude in selecting a destination to visit [18], but up to this point, most researches only focus on investigating this measure [19]. Nevertheless, previous research also suggested that eventhough destination images influences the tourist's travels attitude, but without including and measuring the values, it gives no indication to that traveller of the destination image when deciding a place to visit. In tourism research, consumption values theory act as motivators to choose a destination [20]. Baloglu et al. [21] suggested that analyzing how the consumption values influence the tourists' attitude to visit a destination is important. Previous research has also shown that there is a lack of literature in studying how travelers judge and rate the destination image of destinations they have not visited [22]. Therefore, this research examined how is the consumption values of Indonesia and Thailand's young tourist who have never visited Indonesia and Thailand, and the relationship between consumption values, electronic word of mouth, and their intention to visit the country.

\section{Literature Review}

\section{Destination Choice Intention}

Destination choice intention is defined as the decision-making process that determines the choice of a travel destination. Intention is the individual's future behavior that can be defined as the likelihood to act. Intention drives people's behavior when they visit a place. Thus, measuring intention is an appropriate way to predict behavior [23]. The behavioral intention associated with choosing a 
destination leads to a specific effect on tourists' values, which affects willingness to choose or to continue choosing the service provided. Chang \& Liu [24] stated that intention is a consumer's plan to use a specific service or to enjoy it in a specific destination. It is also stated that destination choice intention will affect the tourists' future behaviour [25]. In this study, behavioural intention is defined as a respondents' anticipation of a future trip or holiday to Indonesia or Thailand for vacation purposes.

\section{Consumption Values}

In marketing literature, consumption values are considered as a significant element for marketing strategy in terms of segmentation and positioning. The consumption values theory can be used to analyze consumer choice behavior. Sheth et al. [26] defines consumption values with five values:

1. Function Value: The perceived utility acquired by an alternative as the result of its ability to perform its functional, utilitarian, or physical purposes. For example as stated by Phau et al [25], a tourist will choose a destination based on the functional values that the destination has such as exotic food, historical site, and quality of infrastructure.

2. Social Value: The perceived utility acquired by an alternative as the result of its association with one or more specific social groups. Alternatives acquire social value through association with positively or negatively stereotyped demographic, socioeconomic and cultural-ethic groups, therefore a tourist will choose the destinations which associated the most with the groups they belong to.

3. Emotional Value: The perceived utility acquired by an alternative as the result of its ability to arouse feelings or affective states.

4. Epistemic Value: The perceived utility acquired by an alternative as the result of its ability to arouse curiosity, provide novelty, and/or satisfy a desire for knowledge.

5. Conditional Value: The perceived utility acquired by an alternative as the result of the specific situation or the context faced by the choice maker. Conditional value focuses on the extrinsic utility rather than intrinsic utility of alternatives. 


\section{Electronic Word of Mouth}

With the improvement of internet technologies nowadays, the number of travellers which use the internet to seek destination information will improve especially between the young generation (Generation Y and Generation Z). Type of exchanging information and knowledge on online and public platform is called Electronic Word of Mouth (eWOM). Thurau et al. [27] defined EWOM as a positive or negative statement of potential, actual and previous customers about a product or company which is made accessible to wider audience through the internet.

\section{Perceived Beneficial Image}

The concept of beneficial image is defined as "perceptions or impressions of a destination held by tourists with respect to the expected benefit or consumption values, including functional, social, emotional, epistemic, and conditional benefits of a destination". These perceptions/ impressions in turn lead to the decision to visit a country as a vacation destination [28]. This definition is based on the theory of market choice behavior suggested by Sheth et al. [26], which suggests that potential tourists will create an image of the destination based on the consumption values, or on beneficial attributes in their evoked set, using this image in the vacation decision process.

\section{Research Design and Method}

The research was conducted in Jakarta city and Bangkok city as the representative of two countries, Indonesia and Thailand. It was conducted in February until April 2020. According to Priyono [29], the sources of data to complete a research are categorized into primary and secondary data. The primary data used in this study was obtained from the research questionnaire which were filled by respondents in Jakarta and Bangkok. Meanwhile secondary data is the data which are collected by previous researchers, official statistic from the government, or individual statistic [29]. The secondary data used in this research were derived from the ASEAN Statistic Website, reports from World Travel and Tourism Council, United Nations World Tourism Organization, Tourism Government in 
Indonesia and Thailand, and marketing companies which are related to the research topic. The sampling method used in this research is non-probability sampling, with purposive sampling technique, in which that is a sampling technique with considerations [30]. While the population for this research is young tourist (15-29 years old) in Jakarta, Indonesia and young tourist in Bangkok, Thailand. This research followed Bentler and Chou [31] theory which stated that the minimum sample should at least be five times of the indicators. This research has approximately 34 indicators, therefore the minimum sample which is suggested according to Bentler and Chou [31] theory is 170 people from each country.

The validity and reliability test of the questionnaire were conducted using IBM SPSS version 25, and the Partial Least Square Structural Equation Modelling was conducted using SmartPLS 3. The conceptual framework of this research can be seen in Figure 2.

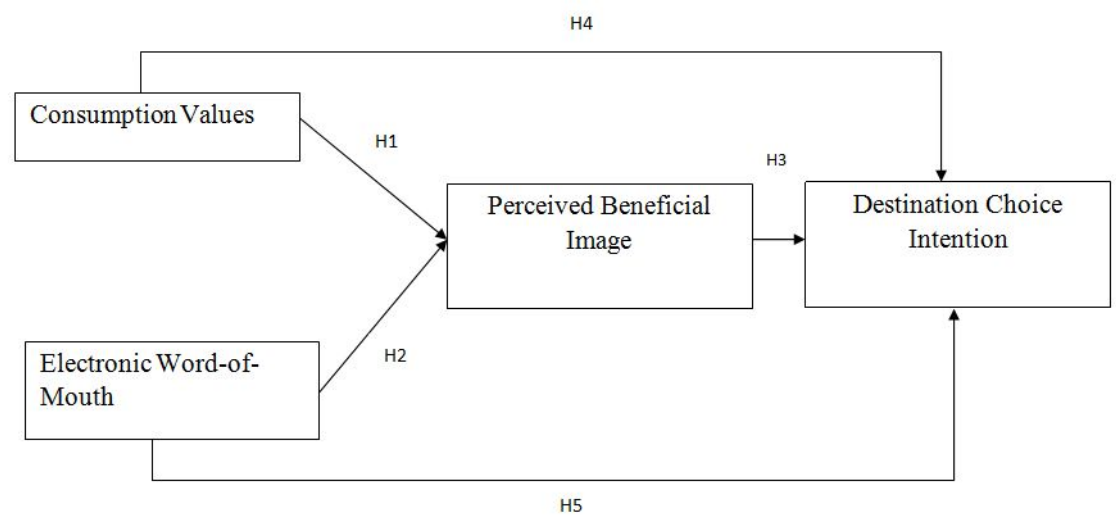

Figure 2. Conceptual Framework of the Research

\section{Result and Discussion}

The respondents for this research were mostly accounted by female respondents for $75 \%$ and age range of $20-24$. Since the target of respondents is potential young tourists, the respondents are also mostly accounted by students. The majority of the income is in the range of $\mathrm{Rp}$. $0-1.000 .000$ for Indonesia 
respondents and more than THB 9000 for Thailand respondents. The monthly income in Thailand is higher than Indonesia because Thailand's income per capita is higher, which is US\$ 6125 while Indonesia's income per capita is only US\$ 4131 (Tradingeconomics, 2019). Another reason is that according to Numbeo [32] for Southeast Asia countries, the living cost for several cities in Thailand such as Bangkok, Phuket, Pattaya, and Chiang Mai is more expensive than living cost in Indonesia, thus making the Thai people having more income than Indonesian to fulfill their needs.

\section{Young Tourists' Perception of Indicators}

This shows young tourist perception of each indicator of each variable. The variables used in this study are consumption values, electronic word of mouth, destination choice intention, and one intervening variable named perceived beneficial image. This research used average calculations to analyze most chosen choices on the questionnaire.

\section{Consumption Values}

From the table 3, it can be assumed that epistemic value dominates the consumption values of young tourist in Indonesia and Thailand. Epistemic value refers to the perceived utility acquired as the result of its ability to arouse curiousity, provide novelty, and satisfy a desire for knowledge [26]. It can be assumed that tourists attractions in both Indonesia and Thailand can be perceived by respondents as in the context of having an opportunity to cognize and learn rather than to acquire functional utility from them. For Thailand's respondent, EP1 in which their intention to visit a country is to learn new culture dominates the score, while for Indonesia's respondent, EP2 in which their intention to visit a country is to experiences new places dominates the score.

Table 3 Consumption Values

\begin{tabular}{lll}
\hline Indicators & Indonesia & Thailand \\
\hline FV1 & 3.6 & 3.4 \\
FV2 & 3.7 & 4.2 \\
FV3 & 3.8 & 3.2 \\
\hline
\end{tabular}




\begin{tabular}{lll}
\hline FV4 & 3.8 & 3.3 \\
FV5 & 3.4 & 3.1 \\
\hline Average of Functional & $\mathbf{3 . 6}$ & $\mathbf{3 . 4}$ \\
Value & & \\
\hline EV1 & 4.3 & 4.3 \\
EV2 & 4.1 & 4.5 \\
EV3 & 3.3 & 3.8 \\
\hline Average of Emotional & $\mathbf{3 . 9}$ & $\mathbf{4 . 2}$ \\
Value & & \\
\hline CV1 & 3.3 & 3.5 \\
CV2 & 2.9 & 3 \\
\hline CV3 & 3.8 & 3.9 \\
CV4 & 3.1 & 3.2 \\
\hline Average of Conditional & $\mathbf{3 . 3}$ & $\mathbf{3 . 4}$ \\
Value & & \\
\hline SC1 & 3.5 & 3.8 \\
\hline SC2 & 3.2 & 3.7 \\
\hline Average of Social Value & $\mathbf{3 . 3}$ & $\mathbf{3 . 7}$ \\
\hline EP1 & 4.5 & 4.2 \\
\hline EP2 & 4.1 & 4.6 \\
\hline EP3 & 4.1 & 4.1 \\
\hline Average of Epistemic & $\mathbf{4 . 2}$ & $\mathbf{4 . 3}$ \\
Value & & \\
\hline
\end{tabular}

\section{Electronic Word of Mouth}

Based on the table 6, young tourist in Indonesia and Thailand have the same average score for their perception of Electronic Word of Mouth. Mauri and Minazzi [33] revealed that information shared by tourist in social media websites significantly influenced young travellers' travel experiences.

Table 4 Electronic Word of Mouth

\begin{tabular}{lll}
\hline Indicators & Indonesia & Thailand \\
\hline
\end{tabular}




\begin{tabular}{lll}
\hline EWOM1 & 4.1 & 4.1 \\
EWOM2 & 4.1 & 4.1 \\
EWOM3 & 2.9 & 2.8 \\
EWOM4 & 3.6 & 3.8 \\
EWOM5 & 4 & 4.1 \\
Average & $\mathbf{3 . 8}$ & $\mathbf{3 . 8}$ \\
\hline
\end{tabular}

\section{Perceived Beneficial Image}

Based on the table 5, for the subvariable of Relaxation and Escape, Thailand has the higher average score. This can be concluded that Thai young tourists find Indonesia as a country where they can relax and escape from their routine. While for attractiveness of destination, Indonesia has the higher score than Thailand which can be concluded that Indonesia young tourists find Thailand more attractive as a destination for holiday.

Table 5 Perceived Beneficial Image

\begin{tabular}{|c|c|c|}
\hline Indicators & Indonesia & Thailand \\
\hline RE1 & 3.9 & 3.7 \\
\hline RE2 & 3.7 & 3.9 \\
\hline RE3 & 3.6 & 3.8 \\
\hline RE4 & 2.7 & 3.4 \\
\hline $\begin{array}{l}\text { Average of Relaxation } \\
\text { and Escape }\end{array}$ & 3.5 & 3.7 \\
\hline A1 & 3.5 & 3.5 \\
\hline A2 & 3.7 & 3.4 \\
\hline A3 & 3.5 & 3.3 \\
\hline A4 & 3.7 & 3.3 \\
\hline A5 & 3 & 3.2 \\
\hline $\begin{array}{l}\text { Average } \\
\text { Attractiveness } \\
\text { Destination }\end{array}$ & 3.5 & 3.4 \\
\hline
\end{tabular}




\section{Destination Choice Intention}

From table 6, it can be assumed that Indonesia young tourists have more intention to visit Thailand. This is also corresponding with the data from Scoot Airlines [7] which showed that Bangkok is the favorite travel destination for Indonesian millenials.

Table 6 Consumer's perception of Destination Choice Intention

\begin{tabular}{lll}
\hline Indicators & Indonesia & Thailand \\
\hline DC1 & 3.5 & 2.8 \\
DC2 & 3.1 & 3.3 \\
DC3 & 3.2 & 2.9 \\
Average & $\mathbf{3 . 3}$ & $\mathbf{3}$ \\
\hline
\end{tabular}

\section{Results of Study Using Structural Equation Modelling Analysis Outer Model Analysis}

This analysis was conducted to understand and measure the relationship between latent variables and the indicators. The reliability of the research model was measured using the values of rho, composite reliability (CR), and average variance extracted (AVE). Indicators with rho indexes above 0,7 [34]; CR values above 0.8 [35]; and loading factors above 0.6 [36] are considered reliable. 


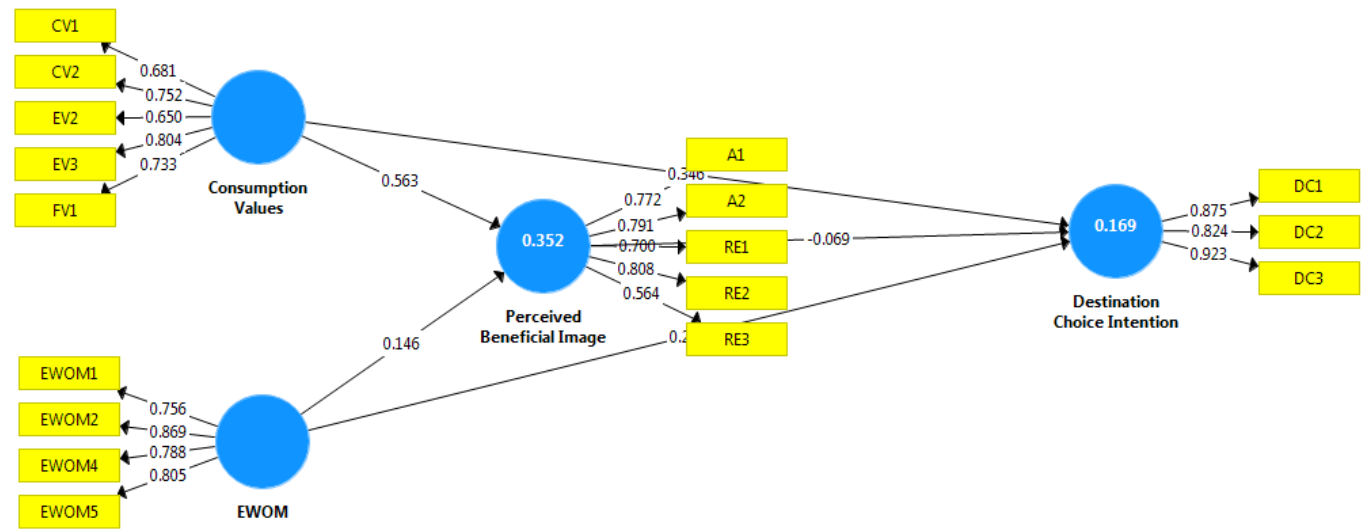

Figure 3. Indonesia's Final Model

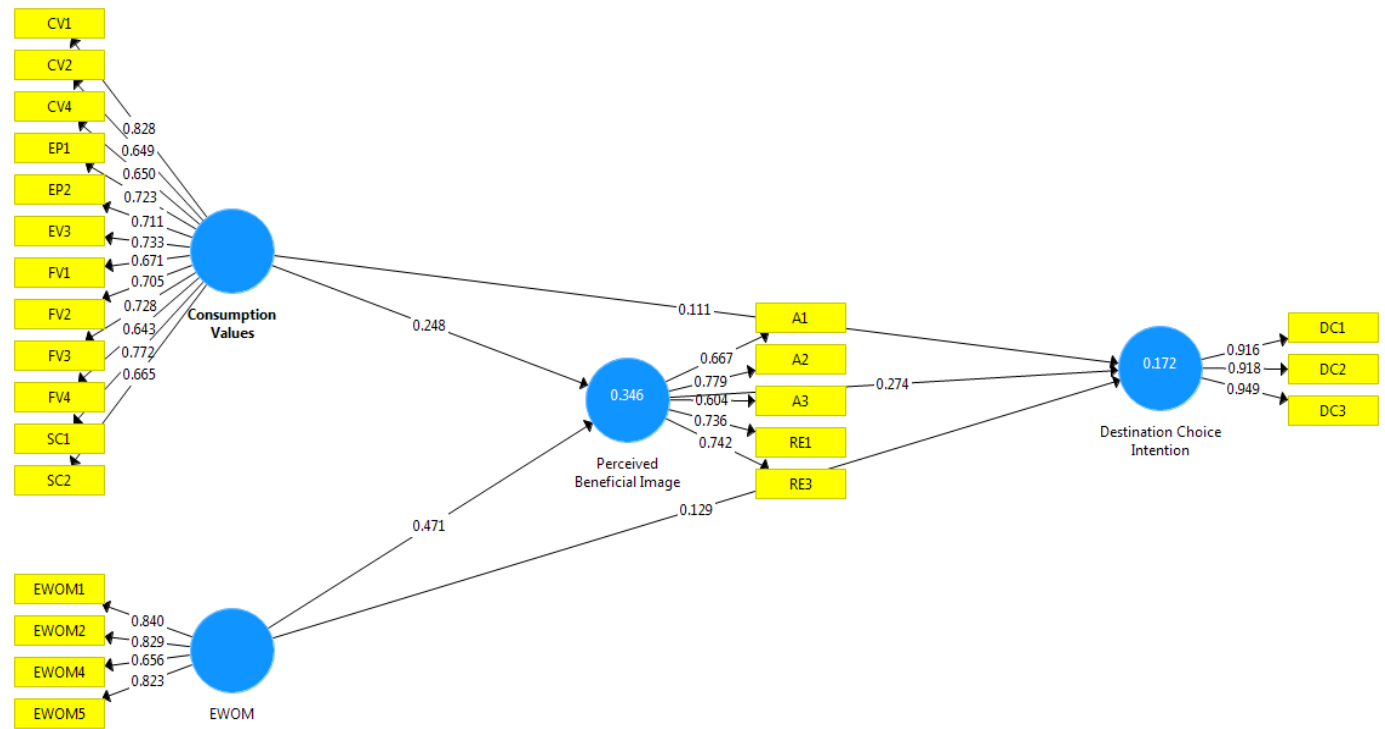

Figure 4. Thailand's final model 
The final model of the research can be seen in Figure 3 and 4. For Indonesia final model, there were seventeen indicators which did not meet the requirements, namely CV3, CV4, EP1, EP2, EP3, EV1, FV2, FV3, FV4, FV5, SC1, SC2, EWOM3, A3, A4, A5, and RE4. While for Thailand final model, there were only ten indicators which needed to be removed, namely CV3, EP3, EV1, EV2, FV5, EWOM3, A4, A5, RE2, and RE4. These showed that these indicators could not reflect the variables well.

Table 7 Test Results of Indonesia's model cronbach's alpha, composite reliability (CR), and average variance extracted (AVE)

\begin{tabular}{llll}
\hline & $\begin{array}{l}\text { Cronbach's } \\
\text { Alpha }\end{array}$ & CR & AVE \\
\hline $\begin{array}{l}\text { Consumption } \\
\text { Values }\end{array}$ & 0.776 & 0.786 & 0.527 \\
\hline EWOM & 0.821 & 0.851 & 0.649 \\
\hline $\begin{array}{l}\text { Perceived } \\
\text { Beneficial Image }\end{array}$ & 0.778 & 0.791 & 0.537 \\
\hline $\begin{array}{l}\text { Destination } \\
\text { Choice Intention }\end{array}$ & 0.846 & 0.859 & 0.765 \\
\hline
\end{tabular}

Table 8 Test Results of Thailand's model cronbach's alpha, composite reliability $(\mathrm{CR})$, and average variance extracted (AVE)

\begin{tabular}{llll}
\hline & $\begin{array}{l}\text { Cronbach's } \\
\text { Alpha }\end{array}$ & CR & AVE \\
\hline $\begin{array}{l}\text { Consumption } \\
\text { Values }\end{array}$ & 0.909 & 0.923 & 0.502 \\
\hline EWOM & 0.801 & 0.868 & 0.625 \\
\hline $\begin{array}{l}\text { Perceived } \\
\text { Beneficial Image }\end{array}$ & 0.753 & 0.833 & 0.502 \\
\hline $\begin{array}{l}\text { Destination } \\
\text { Choice Intention }\end{array}$ & 0.921 & 0.949 & 0.861 \\
\hline
\end{tabular}


To check the model's reliability, it can be conducted by analyzing the value of Cronbach's Alpha and CR. If the value of Cronbach's Alpha and CR are higher than 0.7 , the research model can be stated as reliable.

\section{Inner Model Analysis}

The inner model analysis is conducted by measuring the R-Square values. The R-square value is examined to measure the level of variation in changes in the independent variables on the dependent variable [37]. For Indonesia model, based on the Figure 3, the R square values for the final model is 0.352 and 0.169 . This means for the Indonesia model, perceived beneficial image can be explained by the variables of consumption values and EWOM for as much as 35.20 percent and the destination choice intention can be explained for as much as 16.90 percent. While for Thailand model, based on the Figure 4, the R square values of the Thailand final model is 0.346 and 0.172 . This means that for the Thailand model, perceived beneficial image can be reflected by the variables of consumption values and EWOM for as much as 34.26 percent and the destination choice intention can be explained by the variables of consumption values, EWOM, and perceived beneficial image for as much as 17.20 percent.

Based on the category by Chin [38]; where the R-Square value is divided into substansial (0.67), moderate (0.33), and weak (0.19), both of Indonesia and Thailand model for the intervening variable falls into the category of moderate with 0.352 and 0.346 while for the endogenous variable, the value fall in weak category with 0.169 and 0.172 . This means that the endogenous variables could be explained with more variables outside this research.

The path coefficient values indicate the significance level for the hypothesis testing result. The results have significant effect if the T-statistic value is greater than 1.96 .

Table 9 Path Coefficent Result for Indonesia Research Model

$\begin{aligned} & \text { Original } \\ & \text { Sample }\end{aligned}$
T-Statistics




\begin{tabular}{lllll}
\hline $\begin{array}{l}\text { Consumption Values } \\
\text {-> Destination } \\
\text { Choice Intention }\end{array}$ & $\mathbf{0 . 3 4 6}$ & $\mathbf{3 . 9 6 8}$ & $\mathbf{0 . 0 0 0}$ & Significant \\
\hline $\begin{array}{l}\text { Consumption Values } \\
\text {-> Perceived } \\
\text { Beneficial Image }\end{array}$ & $\mathbf{0 . 5 6 3}$ & $\mathbf{1 0 . 5 6 2}$ & $\mathbf{0 . 0 0 0}$ & Significant \\
\hline $\begin{array}{l}\text { EWOM -> } \\
\text { Destination Choice }\end{array}$ & $\mathbf{0 . 2 5 4}$ & $\mathbf{4 . 1 9 4}$ & $\mathbf{0 . 0 0 0}$ & Significant \\
\begin{tabular}{l} 
Intention \\
\hline $\begin{array}{l}\text { EWOM -> Perceived } \\
\text { Beneficial Image }\end{array}$
\end{tabular} & $\mathbf{0 . 1 4 6}$ & $\mathbf{2 . 0 7 9}$ & $\mathbf{0 . 0 3 8}$ & Significant \\
\hline $\begin{array}{l}\text { Perceived Beneficial } \\
\text { Image -> Destination } \\
\text { Choice Intention }\end{array}$ & -0.069 & 0.777 & 0.438 & Not \\
\hline
\end{tabular}

Table 10 Path Coefficient Result for Thailand Research Model

\begin{tabular}{lllll}
\hline & $\begin{array}{l}\text { Original } \\
\text { Sample }\end{array}$ & T-Statistics & P Values & Hypothesis \\
\hline $\begin{array}{l}\text { Consumption Values } \\
\text {-> Destination } \\
\text { Choice Intention }\end{array}$ & 0.111 & 1.334 & 0.183 & $\begin{array}{l}\text { Not } \\
\text { significant }\end{array}$ \\
\hline $\begin{array}{l}\text { Consumption Values } \\
\text {-> Perceived } \\
\text { Beneficial Image }\end{array}$ & $\mathbf{0 . 2 4 8}$ & $\mathbf{3 . 3 1 5}$ & $\mathbf{0 . 0 0 1}$ & Significant \\
\hline $\begin{array}{l}\text { EWOM -> } \\
\text { Destination Choice }\end{array}$ & 0.129 & 1.542 & 0.124 & Not \\
Intention & & & & significant \\
\hline $\begin{array}{l}\text { EWOM -> Perceived } \\
\text { Beneficial Image }\end{array}$ & $\mathbf{0 . 4 7 1}$ & $\mathbf{7 . 3 7 0}$ & $\mathbf{0 . 0 0 0}$ & Significant \\
\hline
\end{tabular}




\section{Perceived Beneficial \\ 0.274 \\ 3.168 \\ 0.002 \\ Significant Image -> Destination \\ Choice Intention}

Based on the results, $\mathrm{H} 1$ in which consumption values have significance influence on perceived beneficial image and $\mathrm{H} 2$ in which EWOM has significance influence on perceived beneficial image are accepted both for Indonesia and Thailand results. These results are in line with Tapachai \& Waryszak's research [28] which showed that consumption values act as a significant predictor to form perceived beneficial image. This study result also confirmed that eWOM influences the forming of perceived beneficial image of a destination, in which this result is in corresponding the research Jalilvand \& Samiei [39], and also strengthening Balogly $\&$ McCleary theory [40]. In their research, Jalilvand \& Samiei [39] found that eWOM influences the forming of a product's brand image, while Baloglu \& McCleary research [40] stated that the information resources has a significant influence in forming a destination image.

There are some differences on the effects of perceived beneficial image on destination choice intention for both countries. For Indonesian youths, perceived beneficial image of Thailand does not affect their destination choice intention while for Thai youths, perceived beneficial image of Indonesia is a significant predictor for their destination choice. According to Tapachai and Wayszak [28], destination image influences tourists' decision to visit particular vacation destination. The result for Thai youths is corresponding with the research by Phau et al. [25] which showed that perceived beneficial image as a whole has significant effect on destination choice intention, but only one of the two individual factors significantly influences the dependent variable. Though destination image has been widely studied as a significant predictor for visit intention, according to Gallarza \& Calderon [41] the image is always subjective and it is always corresponding to an internal processing of some perception, and not everyone has the same perceptions. The results seem to point that Indonesia and Thai youths have different perceptions of destination image as a predictor for their destination choice. 
For Indonesia youth, consumption values have a significant effect for their destination choice while for Thai youths, it does not. The result for Indonesia is corresponding the previous findings (Gill et al., 2007 [42]; Ming-Sung et al., 2009 [43]; Xiao \& Kim, 2009 [44]) which showed that consumption values as a whole have direct effect on destination choice intention. But according to Ramayah et. al (2016) [45] out of 5 consumption values theory, only two values have significant influence on intention to purchase online shopping in Malaysia. The difference results of Indonesia and Thailand seem to point that further research of consumption values theory is needed, as for this research only studied consumption values as a whole concept.

For the eWOM variable, according to Jalilvand and Samiei [39], eWOM in tourism context has a significant and direct influence on the tourists' attitude to visit a destination. But this study provides unique result, as eWOM is a significant predictor for Indonesia youth to choose Thailand as their destination choice, while for Thai youths EWOM does not have significant influence to choose Indonesia as a destination choice. With the fact that Indonesia and Thailand have a high percentage of internet users in ASEAN with Indonesia having 50,4\% of the population and Thailand with $60 \%$ of the population, this could mean that Indonesia still does not have a good online marketing for its tourism industry, as the EWOM variable still does not have a significant influence for Thai people to visit Indonesia.

\section{Managerial Implications}

According to the results, consumption values and electronic word of mouth are significant predictors in forming tourists destinations' perceived beneficial image. Understanding consumption values and the impacts on destination choice intention is applicable for destination marketing organizations. The consumption values theory provide insights in which value has the higher score from the potential tourists' perception which can be seen in Table 3 of this research.

Destination marketing organizations should highlight epistemic, emotional, and functional values due to the higher score of perception in both countries. Indonesia and Thailand seem to be judged excellently for its functional values, 
therefore, destination marketing organizations in both countries should keep improving their functional values such as the quality of structure and quality of food. Especially after the COVID-19 situation, which highly impact the tourism industry. A research by Hong et al. [46] showed that the priorities of tourist in choosing accommodation for their holiday is changing; for example now tourist prefer single and scattered room layout, more naturally ventilated room, accommodation with complete emergency facilities, etc. Just like after SARS in 2003, tourist tend to go to places with nature-based areas. This could also be the implication in improving and designing new strategies for both countries' functional values for the after COVID-19 situation.

The perceptions' scores of epistemic and emotional value are also quite high and these imply that tourists are very attentive on issues like having fun, escaping routine, relaxing and experiencing different places. This indicates that those issues could be the main attributes that young tourists are looking in their destinations for holiday; therefore, Indonesia and Thailand should improve their strategies to be positioned as the destination which could meet those emotional and epistemic values.

This finding can be implemented in developing marketing strategies, with considering young tourist's perceptions of value which have direct contribution to destination branding, promotional strategies, and market segmentation. This study also showed that the consumption values of young travellers in Indonesia and Thailand have different results which means that destination organization marketing should provide a strategy which can widely reach all potential young tourists.

As for the EWOM, the destination marketing organization in both Indonesia and Thailand could try to provide a platform and encourage young tourist to participate in online discussion as when the volume of tourist reviews on a destination is high, the more information about a destination will disseminate and as a result, the possibility of choosing the destination will increase. Both Indonesia and Thailand's tourism organization actually already had official website and social media to promote their tourism. As for Thailand, they have www.tourismthailand.org and Indonesia has www.indonesia.travel. Both of these 
websites provide complete guide and information about tourism in each country, but they still do not provide a platform where tourists can discuss and do review in their official website. It is very important to notice that eWOM information within the tourists is different from the information provided by tourism organization. eWOM is a two-way exchange of information and has no commercial motive, therefore eWOM has bigger influence on the decision making process compared to the information provided by official tourism organization.

\section{Conclusion and Recommendation}

\section{Conclusion}

1. For Thailand's young tourists, the consumption values which dominate their motivation to visit a country is the epistemic value, which is related to human's desire for knowledge. This imply that a country's attractions is important for them as in the context of visiting the attractions will gain them an opportunity to cognize and learn rather than to acquire functional utility from them. Meanwhile for the perceived beneficial image of Indonesia which is acquired by the Thailand's young tourists, the perception scores of relaxation and escape subvariable dominates the score. This can be concluded that Thai young tourists find Indonesia as a country where they can relax and escape from their routine.

2. For Indonesia's young tourists, the consumption values which dominate their motivation to visit a country is the same as Thailand's respondents, which is the epistemic value. While for the perceived beneficial image of Thailand which is acquired by Indonesia's young tourists is that Thailand is a country which is good and attractive for holiday. The attractiveness of Thailand's is related to its price and cost to travel, economic development, and family-oriented destination.

3. The results of hypothesis testing in Indonesia and Thailand are different. For Indonesia, out of five hypotheses, four hypotheses are accepted while for Thailand only three hypotheses are accepted. In both countries, consumption values and eWOM have significant influence on perceived beneficial image. Consumption values and eWOM have significant influence on destination choice intention to Thailand for Indonesia young tourist, while perceived 
beneficial image only has significant influence on destination choice intention to Indonesia for Thailand young tourist. From the results, it can be concluded that Indonesia and Thailand young tourists have different perception on consumption values effects. Therefore, destination marketing organization should develop different strategies to attract Indonesia and Thailand young tourists.

\section{Recommendation}

The recommendations that can be given by researcher are that destination marketing organization can review their promotion and marketing strategies that have been executed and keep improving their marketing strategies as young travellers will dominate the tourism industry in the future. The details of recommendation of actions that could be taken have been stated in the managerial implications.

The limitation of this research is that this research only studied consumption values theory as a whole concept, so further research to study consumption value on tourism context is needed. The reference for this study is also still limited because this study is still relatively new, therefore it is necessary to look for deeper references to strengthen the results. Further research is also suggested to conduct broader research such as making comparisons with other countries outside ASEAN which have different cultures than Indonesia and Thailand. In addition, further research can also examine other variables that could be predictors of a potential tourists' destination choice intention.

Acknowledgments. The authors acknowledge funding support from the International Collaboration Office of IPB University and Department Management of IPB University, collaborating with Faculty of Business Administration Kasetsart University via Research Attachment Program. 


\section{References}

[1] [WTTC] World Travel \& Tourism Council. 2016. Travel \& Tourism Investment in ASEAN [internet]. [Accessed on 15th November 2019]. Retrieved from https://www.wttc.org/publications/2016/travel-and-tourism-investment-in-asean/

[2] [ASEAN] Association of Southeast Asian Nations Tourism. 2015. ASEAN Information [internet]. [Accessed on 1st November 2019]. Retrieved from http://www.aseantourism. travel/content/about-asean-tourism

[3] Knoema Statistic. 2018. Indonesia - Contribution of travel and tourism to GDP as a share of GDP [internet]. [Accessed on 1st September 2020]. Retrieved from https://knoema.com/atlas/Indonesia/topics/Tourism/Travel-and-Tourism-TotalContribution-to-GDP/Contribution-of-travel-and-tourism-to-GDP-percent-of$\underline{\text { GDP }}$

[4] World Travel \& Tourism Council. 2017. Travel \& Tourism Investment in ASEAN [internet]. [Accessed on 15th November 2019]. Retrieved from https://www.wttc.org/publications/2017/travel-and-tourism-investment-in-asean/

[5] ASEAN Data Statistics. 2020. Visitors to ASEAN Countries [internet]. [Accessed on 10th January 2020]. Retrieved from https://www.aseanstats.org

[6] [UNWTO] United Nations World Tourism Organization. 2016. Global Report on The Power of Youth Travel. Retrieved from http://cf.cdn.unwto.org/sites/all/files/pdf/wyse_powerofyouthtravel.pdf

[7] Jakarta Globe. 2018. Bangkok the Top Destination Among Indonesian Millenial Travelers [internet]. [Accessed on 5th November 2019]. Retrieved from https://jakartaglobe.id/context/bangkok-the-top-destination-among-indonesian$\underline{\text { millennial-travelers/ }}$

[8] Thailand Embassy. 2019. Thais becoming outbound tourists in greater numbers [internet]. [Accessed on 5th January 2020]. Retrieved from https://thaiembdc.org/2019/04/15/thais-becoming-outbound-tourists-in-greaternumbers/ 
[9] Debski Maciej, Nasierowski, Wojciech. 2017. Criteria for the Selection of Tourism Destinations by Students from Different Countries. Foundations of Management. 9(1): 1-14.

[10] [WEF] World Economic Forum. 2019. The Travel \& Tourism Competitiveness Report 2019 [internet]. [Accessed on 5th January 2020]. Retrieved from https://www.weforum.org/reports/the-travel-tourismcompetitiveness-report-2019/

[11] ASEAN. 2017. First ASEAN Youth Development Index (YDI) [internet]. [Accessed on 1st November 2019]. Retrieved from https://asean.org/storage/2017/10/ASEAN-UNFPA_report_web-final-05sep.pdf

[12] Twissen. 2017. Generation Z Impacts on Families Travel Choices [internet]. [Accessed on 20th November 2019]. Retrieved from https://twissen.com/travellers/generation-z-impacts-on-families-travel-choices/

[13] Virtuoso. 2020. The Top Travel Trends for 2020 [internet]. [Accessed on $20^{\text {th }}$ November 2019]. Retrieved from https://blog.virtuoso.com/tips-and-trends/toptravel-trends-for-2020/

[14] Litvin, S.W., Goldsmith, R.E. and Pan, B. 2008. Electronic Word-of-Mouth in Hospitality and Tourism Management. Tourism Management, 29, 458-468. https://doi.org/10.1016/j.tourman.2007.05.011

[15] Leask, Anna \& Fyall, Alan \& Barron, Paul. 2014. Generation Y: An Agenda for Future Visitor Attraction Research. International Journal of Tourism Research. https://doi.org/16. 10.1002/jtr.1940

[16] Nafi, Shohel \& Ahmed, Tanvir. 2018. Travel and Leisure Activities, Motivation and Behavior of Young Bangladeshi Tourists. European Scientific Journal. 14. 10.19044/esj.2018.v14n5p341.

[17] Heesup Han, Wansoo Kim \& Kiattipoom Kiatkawsin. 2017. Emerging youth tourism: fostering young travelers' conservation intentions, Journal of Travel \& Tourism Marketing, 34:7, 905-918, DOI: 10.1080/10548408.2016.1261758 
[18] Gallarza MG, Saura IG, García HC. 2002. Destination image: Towards a conceptual framework. Annals of tourism research. 29(1): 56-78.

[19] Chen JS, Hsu CH. 2000. Measurement of Korean tourists' perceived images of overseas destinations. Journal of Travel Research. 38(4): 411-416.

[20] Gill D, Byslma B, Ouschan R. 2007. Customer perceived value in a cellar door visit: The impact on behavioral intentions. International Journal of Wine Business Research. 19(4): 257-275.

[21] Baloglu S, Henthorne T. L, Sahin S. 2014. Destination image and brand personality of Jamaica: A model of tourist behavior. Journal of Travel \& Tourism Marketing. 31(8): 1057-1070.

[22] Prebensen N. 2007. Exploring tourists' images of a distant destination. Tourism Management. 28: 747-756

[23] Phau I, Quintal V, Shanka T. 2014. Examining a consumption values theory approach of young tourists toward destination choice intentions. International Journal of Culture, Tourism and Hospitality Research. 8(2): 125-139.

[24] Chang, H. H., \& Liu, Y. M. 2009. The impact of brand equity on brand preference and purchase intentions in the service industries. The Service Industries Journal, 29(12), 1687-1706.

[25] Phau I, Quintal V, Shanka T. 2014. Examining a consumption values theory approach of young tourists toward destination choice intentions. International Journal of Culture, Tourism and Hospitality Research. 8(2): 125-139.

[26] Sheth, J. N., Newman, B. I., \& Gross, B. L. 1991. Why we buy what we buy: A theory of consumption values. Journal of Business Research, 22(2), 159-170.

[27] Thurau, T. H., \& Gianfranco, W. 2004. Word of mouth: Motives for and consequences of reading customer articulations on the internet. International Journal of Electronic Commerce, 8(2), 51-74. 
[28] Tapachai, Nirundon \& Waryszak, Robert. 2000. An Examination of the Role of Beneficial Image in Tourist Destination Selection. Journal of Travel Research J TRAVEL RES. 39. 37-44. 10.1177/004728750003900105.

[29] Priyono. 2016. Metode Penelitian Kuantitatif. Sidoarjo: Zifatama Publishing. [30] Sugiyono. 2011. Metode Penelitian Kuantitatif, Kualitatif dan R\&D. Bandung: Afabeta

[31] Bentler, P.M. and Chou, C. (1987) Practical Issues in Structural Modeling. Sociological Methods and Research, 16, 78- 117. http://dx.doi.org/10.1177/0049124187016001004

[32] Numbeo. 2020. South-Eastern Asia: Current Cost of Living Index by City [Internet]. [Accessed on 1st September 2020]. Retrieved from https://www.numbeo.com/cost-of-living/region rankings current.jsp?region $=035$

[33] Mauri, A.G., Minazzi, R. 2013. Web reviews influence on expectations and purchasing intentions of hotel potential customers. International Journal of Hospitality Management, 34, 99-107

[34] Djikstra, T. K., \& Henseler, J. 2015. Consistent partial least squares path modeling. MIS Quarterly, 39(2), 297-316.

[35] Nunnally, J. C., \& Bernstein, I. H. 1994. Psychometric theory. New York: McGraw Hill.

[36] Bagozzi, R. P., \& Yi, Y. 1988. On the evaluation of structural equation models. Journal of the Academy of Marketing Science, 16(1), 74-94.

[37] Abdillah W, Jogiyanto H. 2015. Partial Least Square (PLS Alternatif Structural Equation Modelling (SEM) dalam Penelitian Bisnis. Yogyakarta (ID): Andi Offset.

[38] Chin WW. 1998. The Partial Least Squares Approach to Structural Equation Modeling. Modern Methods for Business Research. London (UK): Lawrence Erlbaum Associates. 295-336. 
[39] Reza Jalilvand, M. and Samiei, N. 2012. The impact of electronic word of mouth on a tourism destination choice. Internet Research, Vol. 22 No. 5, pp. 591612. https://doi.org/10.1108/10662241211271563

[40] Baloglu, S. and McCleary, K.W. (1999) A Model of Destination Image Formation. Annals of Tourism Research, 26, 868-897. http://dx.doi.org/10.1016/S0160-7383(99)00030-4

[41] Gallarza, M. G., Saura, I. G., \& García, H. C. 2002. Destination image: Towards a conceptual framework. Annals of tourism research, 29(1), 56-78.

[42] Gill, D., Byslma, B., \& Ouschan, R. 2007. Customer perceived value in a cellar door visit: The impact on behavioral intentions. International Journal of Wine Business Research, 19(4), 257-275.

[43] Ming-Sung, J., Shih-Tse Wang, E., Ying-Chao, J., \& Vivek, S. D. 2009. Why do customers utilize the internet as a retailing platform? A view from consumer perceived value. Asia Pacific Journal of Marketing and Logistics, 21(1), 144-160.

[44] Xiao, G., \& Kim, J. O. 2009. The investigation of Chinese consumer values, consumption values, life satisfaction, and consumption behaviors. Psychology \& Marketing, 26(7), 610-624.

[45] Ramayah, T. \& Rahman, Syed Abidur \& Ling, Ng. 2018. How do Consumption Values Influence Online Purchase Intention among School Leavers in Malaysia?. Review of Business Management. 20. 638-654. 10.7819/rbgn.v0i0.3139.

[46] Hong, Y.; Cai, G.; Mo, Z.; Gao, W.; Xu, L.; Jiang, Y.; Jiang, J. 2020. The Impact of COVID-19 on Tourist Satisfaction with B\&B in Zhejiang, China: An Importance-Performance Analysis. Int. J. Environ. Res. Public Health 2020, 17, 3747. 